\title{
Sensitivity of Amazon Regional Climate to Deforestation
}

\author{
Lincoln Muniz Alves ${ }^{1}$, Jose A. Marengo², Rong Fu³, Rodrigo J. Bombardi ${ }^{4}$ \\ ${ }^{1}$ Earth System Science Center (CCST), National Institute for Space Research (INPE), São José dos Campos, São Paulo, Brazil. \\ 12227-010 \\ ${ }^{2}$ National Center for Monitoring and Early Warning of Natural Disasters (CEMADEN), São Paulo, Brazil \\ ${ }^{3}$ Dept. of Geological Sciences, Jackson School of Geosciences, University of Texas at Austin, Austin, Texas, USA \\ ${ }^{4}$ Dept. of Atmospheric, Oceanic and Earth Sciences, College of Science, George Mason University, Fairfax, VA, USA \\ Email: *lincoln.alves@inpe.br
}

How to cite this paper: Alves, L.M., Marengo, J.A., Fu, R. and Bombardi, R.J. (2017) Sensitivity of Amazon Regional Climate to Deforestation. American Journal of Climate Change, 6, 75-98.

https://doi.org/10.4236/ajcc.2017.61005

Received: November 17, 2016

Accepted: March 4, 2017

Published: March 7, 2017

Copyright (c) 2017 by authors and Scientific Research Publishing Inc. This work is licensed under the Creative Commons Attribution International License (CC BY 4.0)

http://creativecommons.org/licenses/by/4.0/

\begin{abstract}
It is known that the Amazon region plays an important role in the global energy, hydrological cycle and carbon balance. This region has been suffering from the course of the past 40 years intense land use and land cover changes. With this in mind, this study has examined possible associations between change in spatial and temporal rainfall variability and land cover change in the Amazon, using the PRECIS regional modelling system. It has been found that the impacts of land cover change by forest removal are more intense in the so-called "Arc of deforestation" over central and southern Amazonia. However, the relative impact of the simulated rainfall changes seems to be more important in the JJA dry season. In addition, the simulations under the deforestation scenarios also show the occurrence of extreme rainfall events as well as more frequent dry periods. Therefore, the results found show to be potentially important in the modulation of regional climate variations which have several environmental and socio-economic impacts.
\end{abstract}

\section{Keywords}

Amazonia, Climate Variability, Deforestation, Extreme Events, PRECIS

\section{Introduction}

Over a large part of tropic, the south America east of the Andes, the Amazon rainforest covers an area of $\sim 5.3$ million $\mathrm{km}^{2}$, accounting for $40 \%$ of global tropical forest area and comprises the largest and most biodiversity tract of tropical rainforest in the world [1] [2]. It is known that the Amazon rainforest plays an important role in the global energy, hydrological cycle and carbon balance, and 
has been suffering from the course of the past 40 years intense deforestation [3] [4] [5] [6]. After a long period of massive deforestation, Amazon forest loss dropped dramatically to levels never previously recorded on recent decades. However, more recently, deforestation rates seem to be increasing again and the eastern and southern portion of the basin could continue to be a deforestation hotspot in Brazil. Estimates of the PRODES (Amazon Deforestation Monitoring Project) (INPE 2015) indicate an increase of 24\% from August 2014 to July 2015, compared with the previous period, from August 2013 to July 2014. This is the highest rate in the last four years and deforestation trends have been shown to be more complex, involving social, political and economic factors acting at multiple scales [7] [8].

Precipitation over the Amazon shows a strong spatial-temporal variability. More details about rainfall regimes and their variability in the Amazon basin see [6] [9]-[14], among others. Despite annual rainfall in the Amazon basin being ge-nerally above $2000 \mathrm{~mm}$, about two-thirds of the Amazon forests experience a marked dry season from July to October. The timing and duration of the dry season could be different depending on the year and the location, with more rainfall during austral summer and fall and less rainfall during the austral winter. [15] defines dry month as the months where rainfall is below $100 \mathrm{~mm} / \mathrm{month}$, and this criteria has been widely used [16] [17].

The atmospheric flows of water vapour in South America show that moisture over the Amazon basin comes mainly from the tropical Atlantic Ocean [18] [19]. However, the coupling between atmosphere-ocean-land plays an equally important part in the moisture transport as water-vapour fluxes reveal that a large amount of the Amazon precipitation is due to evapotranspiration from the Amazon basin, especially during the summer [20] [21]. The role of the forest in the water recycling has been explored since the late 1970s [9], and recent work by Makarieva et al. [22] suggests an active role of the vegetation in the regional water cycle. Therefore, land cover changes through atmospheric feedbacks can have a striking impact on the local, regional and even global mean climate as well as climatic extremes and variability [23] [24].

The hydrology of the Amazon region may be affected by extremes dry and wet conditions and those extremes may affect the human systems by means of affecting river transportation, and also the natural systems by means of alteration water and carbon cycles. For instance, droughts in 2005 and 2010 have altered dramatically the hydrology of Amazon river and also the carbon balance, due mainly to an increase in the number of fires and related injection of smoke and aerosols in the regional atmosphere [6] [25] [26] [27] [28] [29] and the references therein.

Land cover change can produce noticeable impacts on the land surface energy balance, hydrological and biogeochemical cycles through modifying the physical properties of the land surface [21] [30] [31] [32] [33]. Through these exchanges, land use change may have a direct influence on the Amazon precipitation pattern [34] [35], and is therefore matter of particular social, economic and environmental 
interest once that the Amazon is home to more than 40 million people, which, despite intense urbanization, still live and depend on the region's natural resources.

Presently, the best way to understand the complex nature of land surface-atmosphere interactions and their impact on rainfall is through land use sensitivity studies using various types of environmental models. The influence of land cover change in the Amazon climate has been widely discussed in observational and modeling studies since the 1980's [23] [32] [36]-[46], and several others. They all agree that in the vast Amazon deforestation scenario, the land cover change may cause a regional climate change, with rainfall reduction and temperature increases in the region. However, the amplitude, sign and distribution of precipitation change differ and depend on the type of model and the methods for describing and representing land use and land cover change.

Recently, Spracklen and Garcia-Carreras [35] arranged all relevant peer-reviewed papers published over the last 40 years based on analysis of model simulations of the impacts of Amazon deforestation (deforested areas varied from $10 \%$ to $100 \%$ ) on rainfall. Results show that more than $90 \%$ of simulations agree on the sign of change and deforestation influences regional rainfall as simulated by the model and in general; it leads to a reduction in rainfall. However, there are some differences between them mainly in term of amplitude, magnitude and predictability that is strongly dependent on the spatial and temporal scales being considered [47] [48] [49] [50] [51]. For instance, the increase in rainfall is mainly observed in smaller deforestation extent, while the majority of experiments with high deforestation rates simulate a reduction in rainfall. Furthermore, the authors alto emphasize that simulated change in rainfall are highly dependent of the climate model-land surface model—used [52].

Furthermore, several studies of Amazon deforestation have indicated that largescale deforestation may lead to warmer surface temperatures and less evaporation and rainfall. For instance, Sampaio et al. [46] used the CPTEC AGCM to demonstrate that land-use changes for pasture and soybean cropland expansion can lead to increases in near-surface air temperature due to increased surface sensible heat flux and decreases in evapotranspiration and precipitation, changes which mainly occur during the dry season. The authors suggest that there might be an apparent tipping point in the precipitation regime following deforestation. There is a significant reduction in precipitation when the area of deforestation exceeds 40\% of the eastern Amazon. Malhi et al. [24] observed that land-use changes might reduce cloudiness, increasing insolation, and enhance land surface reflectance. Fires in the region consequence of drier atmosphere also lead to changes in atmospheric aerosol loading, from biomass burning mainly during the dry season and therefore influence the formation of clouds and precipitation [53].

Lee et al. [54] explored the possible influences of the impact of land cover change by using the NCAR/CAM3 and showed remarkable impacts on precipitation mainly during dry season and in regions of relatively low annual rainfall. They found also that land use change can lead to more surface warming. 
Even in the absence of anthropogenic deforestation, some climate projections indicate a risk of climate change-driven rainforest dieback [55] [56]. In addition to the reduced precipitation predicted under conditions of extensive deforestation, "savannization" consequence of the "dieback" of the Amazon forests is expected in Eastern Amazonia under warming scenarios associated with anthropogenic climate change [57] [58]. Observational studies showed that a reduction regional precipitation in tropical rainforest affected significantly the tree mortality rate and consequently can lead to reduce ecosystem resilience [59].

It should be noted that the majority of simulations and studies have been used GCMs to assess the impact of land use change on climate. However, although these models describe important physical elements and processes in the atmosphere, oceans and land surface that make up the climate system, they have a coarse spatial resolution and cannot represent the fine-scale detail that characterises the regional climate especially in regions with heterogeneous land surface cover [35]. Therefore, use of regional climate models should potential improve the re-presentation of the climate information that is important for impact assessments at a regional level. Improvements in the spatial resolution of the models, realistic land covers and convection schemes, for example Xue et al. [60] that the new vegetated dataset (changes in particular in LAI, soil properties were deemed important) produced significantly different latent heat flux's and surface temperatures which can cause a significantly different response in rainfall and atmospheric circulation. Nonetheless, for South America, few studies have used regional climate models specifically designed to evaluate the effects of anthropogenic land cover and land use change at the scale of the Amazon basin.

Even having significant reduction rates in recent years the deforestation in Brazilian Amazon still has been a dominant theme of global environmental agenda, generating huge concern mainly because the ongoing expansion of cattle and agribusiness in Amazonia, and this is expected to continue over next decades as consequence of rapidly expanding global markets for agricultural commodities, large-scale transportation and energy infrastructure projects, and weak institutions [5] [61]. In addition, various assessments of IPCC and many studies have identified Central and South America, including Amazon basin, as regions with high vulnerability to future climate change [62] [63]. Overall, the Amazon basin is vulnerable through a combination of human influences, including deforestation, fire and climate change [64].

With this in mind, this study is aimed to assess the impact of land use scenarios for the Brazilian Amazon based on the second generation Hadley Centre regional climate model known as PRECIS (Providing Regional Climates for Impacts Studies) [65]. These are the key research questions that drive this study: (a) What is the impact of land surface changes on the climate of Amazon basin, particularly on changes on the seasonal rainfall variability; and (b) Are those changes affecting the timing and duration of the rainy and dry seasons, and in the frequency and intensity of climate extreme events, such as drought and flooding in the region? 


\section{Methods}

\section{Model description and experimental design}

PRECIS was developed at the UK Met Office Hadley Centre as a system for generating high-resolution climate change information for any region of the world. It incorporates a regional climate model RCM in a user-friendly tool in order to gain the necessary scientific and technical knowledge by means of using models and conducting climate change and impacts studies. PRECIS has been used around the world over a broad range of research subjects, including climate vulnerability and impacts: Africa [66]; China [67]; South America [68] [69]; South Asia [70]; Central America and México [71] and the Caribbean [72].

As part of the PRECIS System, the HadRM3P was chosen on the basis that it is not only easy to run but can allow the aims of the study to be achieved in the time available, especially for the land cover studies and climate projections. Another main point to consider was the fact that HadRM3P model does a reasonably good job representing South America climate patterns compared with other models [69] [73]. In fact, simulations from the HadRM3P model climatology for the present climate were presented by Alves and Marengo [69]. This study evaluates the skill of the model to reproduce the seasonal variability of the main climatological characteristics of South America. The results showed that the model was able to reproduce reasonably well the spatial and temporal patterns of the precipitation and temperature as well as the main features of large-scale circulation. However, the authors also remark that the model still has systematic errors that may be due to the model physics and the lateral boundary conditions.

Furthermore, the dynamics of HadRM3P is based on HadAM3P global model that represents the atmospheric component of the HadCM3 coupled model [74] [75]. For further HadAM3P details please see Jones et al. [76].

The HadRM3P shows 19 vertical atmospheric levels and includes MOSES I (Met Office Surface Exchange Scheme version 1.0-Cox et al. [77] with 4 soil levels). In MOSES I, the model parameters which describe soil and land cover (typically vegetation) properties are calculated as geographically varying functions of the soil and land cover types specified in the datasets created by Wilson and Henderson-Sellers [78] (referred to as the WHS). A summary of formulations model physics in PRECIS is given in Jones et al. [65] and Alves and Marengo [69]. The model was run was over the domain of $20^{\circ} \mathrm{S}$ to $20^{\circ} \mathrm{N}$ and $100^{\circ} \mathrm{W}$ to $10^{\circ} \mathrm{W}$ with a $50 \mathrm{~km}$ horizontal resolution.

As part of the "Quantifying Uncertainties in Model Projections" QUMP, experiment [79], various scenarios or members of the HadCM3 global model were obtained to be used as boundary conditions for the RCM simulations. Chou et al. [80] and Marengo et al. [81] describe the runs performed for the QUMP experiment. For this study we used the HadCM3Q0 member.

To analyze the influence of land cover change on the Amazon basin, different sensitivity experiments are performed.Each experiment spans 51 years integration (1960 to 2010), one simulation representing present-day land cover set to datasets created by Wilson and Henderson-Sellers ("WHS") [78] (referred to as 
the control run-CTRL) and two perturbed simulations that use scenarios of deforestation for Amazon produced by Aguiar et al. [61]. The three simulations used the land cover dataset WHS, which specifies 53 classes of vegetation and other land cover.

The deforestation extent was based on the very pessimistic scenario-named scenario $\mathrm{C}$-based on the premise of a regression in the environmental and social advances of the last decade, suggesting that deforestation rates could return to higher levels and ignore the forest Code, allied to a chaotic urbanization process and social problems. For more information about the scenario process and the Land Use and Cover Change (LUCC) modeling framework can be found in Aguiar et al. [61].

In this study, we use two fragmentation tropical rainforest deforestation scenarios for 2030 (referred to as the CEN2030) and 2050 (referred to as the CEN2050). Figure 1 shows the spatial distribution of the deforested areas for 2030 and 2050 used in our deforestation experiments. In these scenarios, deforestation is defined as the replacement of the natural vegetation (WHS) by pasturelands. In this study, the first year is considered as spin-up time and excluded from our analyses and vegetation cover is fixed through the duration of the experiments. The only difference between the simulations is the imposed land cover distribution.

The impact of the land cover is then presented on the basis of precipitation, temperature, evaporation, Bowen ratio, vertical integrated moisture flux changes, defined by the difference between deforestation experiments and control. Besides annual means, seasonal means have also been computed to highlight contrasted behaviours between the dry season, which has been defined from June to August (JJA), and the wet season, from December to February (DJF). For a more spatial detail, the domain has been split into two sub-regions: northeastern Amazon $\left(\mathrm{NEAMZ}, 55^{\circ} \mathrm{W}-45^{\circ} \mathrm{W}, 5^{\circ} \mathrm{S}-2.5^{\circ} \mathrm{N}\right.$ ) and southern Amazon (SAMZ, $70^{\circ} \mathrm{W}-$ $\left.50^{\circ} \mathrm{W}, 12.5^{\circ} \mathrm{S}-5^{\circ} \mathrm{S}\right)$. These regions were chosen because they appear to be particularly sensitive to combination of large-scale historical deforestation, their geographical position in a climatological and ecological transition zone (between Cerrado and semi-arid region) and with a well-defined wet and dry season.

To compute the onset, demise and duration of the rainy season over the subregions we used the methodology originally proposed by Liebmann and Marengo [82] and modified by Bombardi and Carvalho [83]. The method depends only on daily precipitation (Equation (1)), where $S$ is the accumulated precipitation anomaly, $P$ is the precipitation in pentads, and $P_{C}$ is the annual climatological mean.

$$
S=\sum_{t=t_{0}}\left(P(t)-P_{C}\right)
$$

The accumulated precipitation anomalies are computed starting from the dry season (date of the minimum in the precipitation annual cycle, $t_{0}$ ) for each grid point. The $S$ curve will initially have negative values. Once the rainy season is established, the $S$ curve undergoes an inflection and starts to increase. After smoothing the $S$ curve using a 1-2-1 filter, the onset of the rainy season is defined as the 


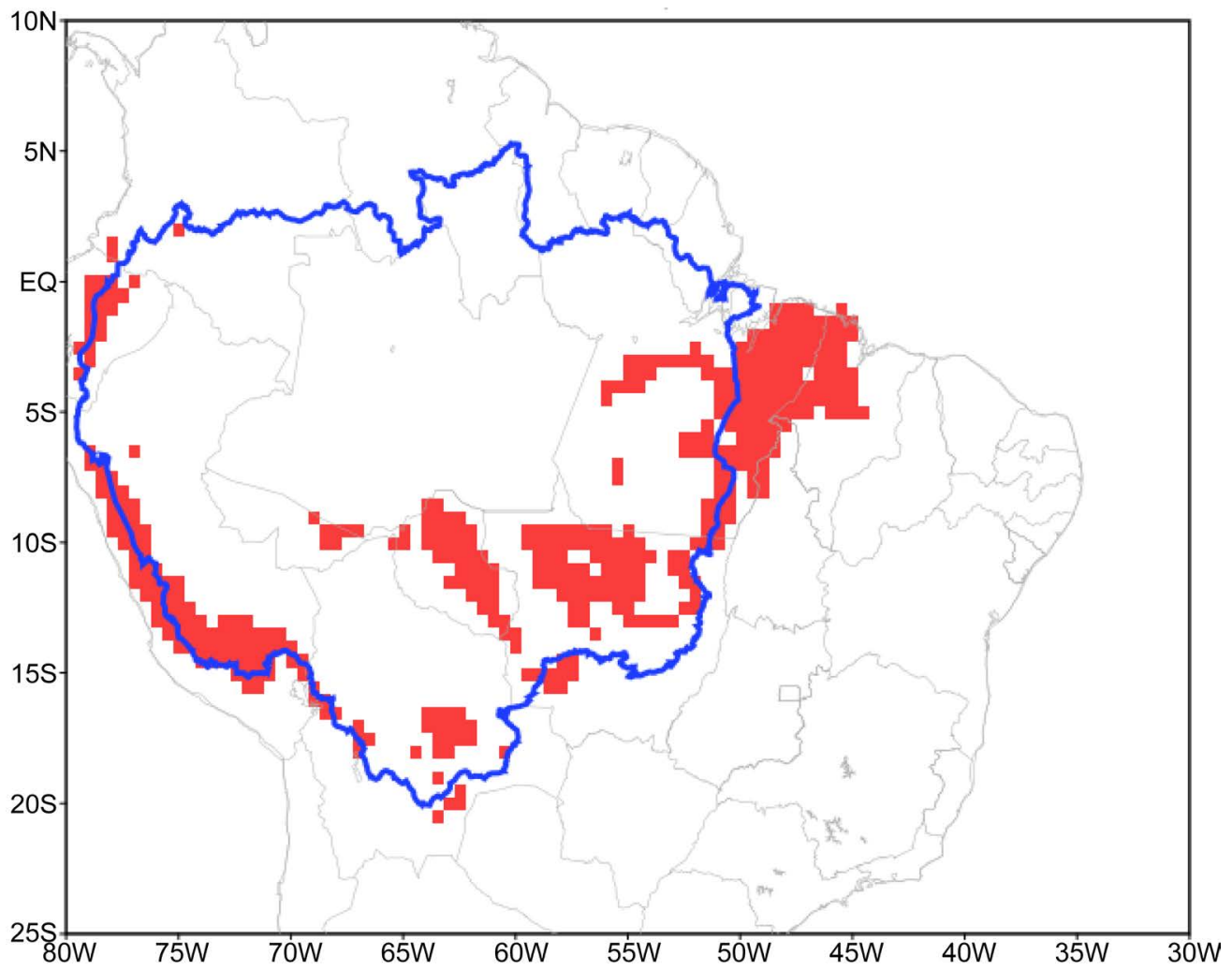

(a)

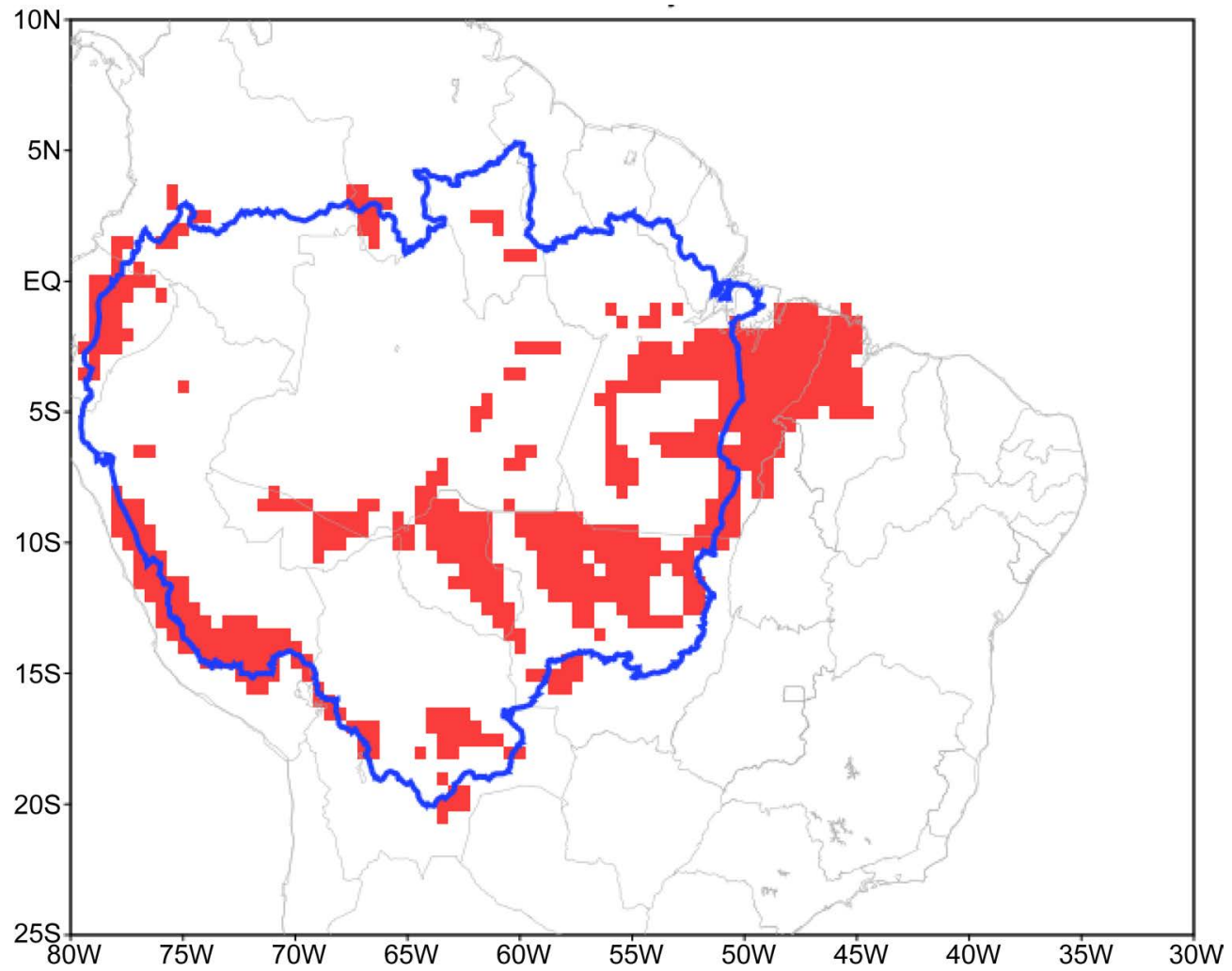

(b)

Figure 1. Spatial distribution of the deforested areas used in the perturbed simulations for: (a) 2030 ( 28\% deforested area) and (b) 2050 ( 38\% deforested area) according to Aguiar et al. (2015). The red rectangles indicate deforested areas replaced to pasture in the RCM. 
date when the first derivative of the smoothed $S$ changes from negative to positive. Likewise, the calculation of the demise of the rainy season starts on the date of the maximum precipitation annual cycle with $S$ starting with positive values. It is important to notice that the application of this method is appropriate since it does not impose any precipitation threshold. Additionally, analyses to assess rainfall extremes were performed using the Standardized Precipitation Index (SPI) developed by Mckee et al. [84] across the Amazon sub-regions. Using precipitation data only the main feature of SPI is that it builds upon the relationships of both wet and dry conditions to frequency, duration and multiple-time scales and allows for several applications. SPI is applicable in all climate regimes, and SPI values for very different climates can be compared. Based on the adjustment of historical precipitation records to the gamma distribution, the SPI quantify the precipitation deficits/excess on temporal and regional basis. The complete description of the computational procedure of SPI can be found in McKee et al. [84], WMO [85] among others. The dry/wet categories resulting from the SPI values as defined in this study are presented in Table 1.

The statistical significance of the differences between the monthly mean precipitation of the control (CRTL) and deforestation simulations (CEN2030 and CEN2050) is checked using the Student's $t$-test [86]. The $t$-test is extensively used for analysis in environmental sciences and it is fairly robust, readily available, and easy to use and interpret.

The $t$-test takes into account, the difference between the means of each sample, the variance $(S)$ and the number of degrees of freedom $(n-1)$, which depends on the sample size $(n)$. The test statistic is calculated as:

$$
t=\frac{\bar{X}_{1}-\bar{X}_{2}}{\sqrt{\frac{S_{1}^{2}}{n_{1}}+\frac{S_{2}^{2}}{n_{2}}}}
$$

where $\bar{X}_{1}\left(\bar{X}_{2}\right)$ are the sample means, $n_{1}\left(n_{2}\right)$ are the sample sizes and $S_{1}^{2}\left(S_{2}^{2}\right)$ are the sample variances.

The $t$-test at the $95 \%$ confidence level was used to consider statistically significant. From this level of confidence and $n-1$ number of degrees of freedom we obtain a reference value $t_{r}$ (http://statpages.org/pdfs.html). The hypothesis that two groups are statistically different is checked if $t$ is greater than $t_{r}$

\section{Results and Discussion}

Changes in seasonal mean precipitation due to the Amazon deforestation (CEN2030 and CEN2050) relative to the control simulation (CTRL) are shown in Figure 2. The land cover change predominantly has a local strong effect on

Table 1. Categories according to SPI values.

\begin{tabular}{cc}
\hline SPI values & Category \\
\hline$[+,-] 2.1$ to $3.0:$ & Extreme [wet, dry] \\
{$[+,-] 1.5$ to $2.0:$} & Severe [wet, dry] \\
\hline
\end{tabular}


precipitation in the core of the deforested region for both the wet and dry seasons as well as the annual mean. Deforestation locally leads to an increase in precipitation (up $4 \mathrm{~mm}$ /day) mainly in summer (DJF). There is also a compensating decrease in rainfall on the north flank of the deforestation areas (Figure 2).

It is noticed that land cover change immediately induced a sudden decrease of evaporation $(-0.7 \mathrm{~mm} /$ day for CEN2050) withwarming of surface air temperature (about $+1^{\circ} \mathrm{C}$ ) (Table 2) across the two subregions, but more pronounced in winter (JJA) and over NEAMZ. The range of temperature change is comparable to that projected by dynamic downscaling forced by Coupled Model Intercomparation Project Phase 3 (CMIP3) models and from different global CMIP5 models used in the IPCC AR5 for various Representative Concentration Pathways (RCPs) (4.5 and 8.5) that can reach up to $1^{\circ} \mathrm{C}-2^{\circ} \mathrm{C}$ for mid-twenty-first century.

In addition, these results follow the same trend of temperature increase due to deforestation of the various simulations of the climatic effects due to land cover change carried out by different authors [23] [38] [40] [46] [87] [88].

The surface temperature much high in the deforested area is expected since we have a decreasing of the evaporation and the lower surface roughness length. This is because deforestation implies less exchange water flux between the surface and the atmosphere, but also stronger wind near the land. Average evaporation decreased from $0.89 \mathrm{~mm} /$ day during the dry season to $0.57 \mathrm{~mm}$ /day during the wet warm season DJF for CEN2050 over NEAMZ relative to the control experiment.

This leads to drier soil and, and this can greatly affects the energy balance at the surface, and consequently the spatial distribution of the sensible and latent heat flux represented here by the Bowen ratio. During the wet season the Bowen
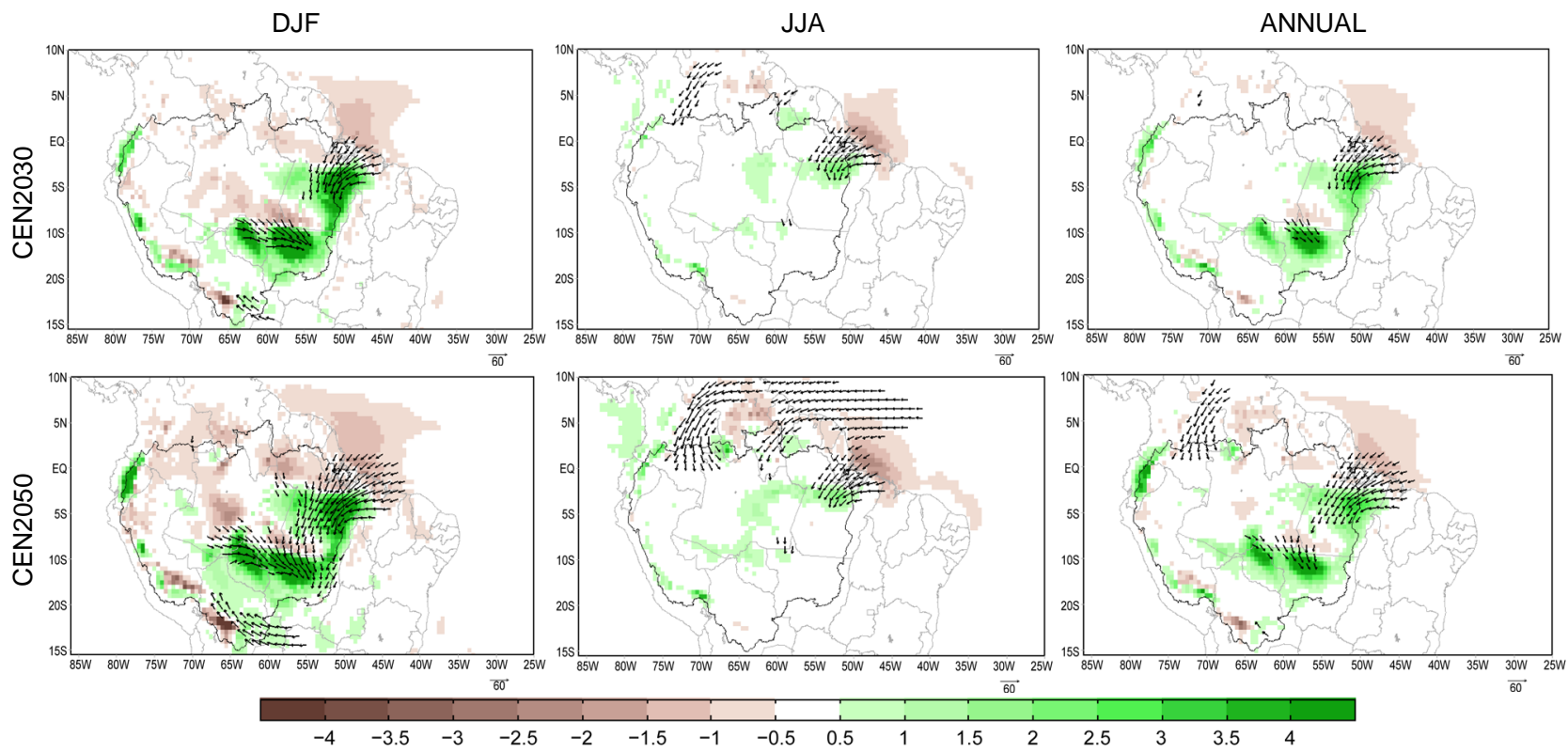

Figure 2. Precipitation (shaded, units: $\mathrm{mm} /$ day) overlaid with vertically integrated moisture flux (vectors, units: $\mathrm{g} / \mathrm{kg}^{\star} \mathrm{m} / \mathrm{s}^{\star} \mathrm{hPa}$ ) for summer (DJF), winter (JJA) and Annual based on difference between deforestation and control runs. Magnitude above 20 $\mathrm{g} / \mathrm{kg}^{\star} \mathrm{m} / \mathrm{s}^{\star} \mathrm{hPa}$ vector is displayed. 
Table 2. Climate differences between deforestation simulations (CEN2030, CEN2050) and control (CTRL) simulation for summer/winter/annual over Southern (SAMZ) and Northeastern (NEAMZ) Amazon.

\begin{tabular}{ccc}
\hline & \multicolumn{2}{c}{ Difference } \\
\hline SAMZ & CEN2030 & CEN2050 \\
\hline Temperature $\left({ }^{\circ} \mathrm{C}\right)$ & $0.5 / 0.7 / 0.6$ & $0.7 / 1.1 / 1.0$ \\
Evaporation $(\mathrm{mm} /$ day $)$ & $-0.38 /-0.49 /-0.46$ & $-0.62 /-0.75 /-0.71$ \\
Precipitation $(\mathrm{mm} /$ day) & $1.491 / 0.126 / 0.742$ & $1.888 / 0.192 / 0.957$ \\
Bowen ratio & $0.13 / 1.97 / 0.26$ & $0.20 / 2.71 / 0.37$ \\
\hline NEAMZ & & $1.1 / 1.4 / 1.1$ \\
Temperature $\left({ }^{\circ} \mathrm{C}\right)$ & $0.8 / 1.0 / 0.8$ & $-0.57 /-0.89 /-0.68$ \\
Evaporation $(\mathrm{mm} /$ day) & $-0.42 /-0.70 /-0.51$ & $0.335 /-0.309 / 0.145$ \\
Precipitation $(\mathrm{mm} /$ day) & $0.513 /-0.084 / 0.297$ & $0.42 / 1.44 / 0.65$ \\
\hline Bowen ratio & $0.29 / 1.12 / 0.48$ & \\
\hline
\end{tabular}

ratio is always lower than the values observed during dry season (Table 2) and reveal that the during this season the latent flux is greater than the sensible heat flux and we usually have an decrease of evaporation. This aspect is coincident with change in precipitation, cloudiness and net radiation during the seasons. In general, the results show that the land cover change is able to change energy fluxes and consequently causing changes in climate variables, such as pressure, circulation and temperature.

Overall, these changes tend to cool the surface. However, the effect of reduction of the evaporation is much greater than the effect of increasing the albedo, and therefore, the temperature increases with the removal of vegetation [38] [89]. In both deforestation simulations, the impacts of the land cover change are more intense over "Arc of deforestation" and central-southern Amazon during the whole year, however, it is worth emphasizing that the relative impact of the simulated changes is greatest in the dry season JJA when the wintertime large-scale circulation interaction are less influential. This is in agreement with Baidya et al. [90] and Saad et al. [91].

In sum, an increase in temperature, decreasing evaporation and surface water deficit due to deforestation would act as positive feedback, and increase the susceptibility of Amazonia ecosystems to increase the incidence of fires and the consequent injection of aerosols into the atmosphere. In fact, several studies conducted during the LBA in the 90s and more recently with Go Amazon experiments, show that aerosols could potentially affect the onset and the quality of the rainy season [53] [92] [93].

Increased rainfall over large deforested areas and decrease in overlying areas is an indication that the changes in latent and sensitive heat fluxes and temperature, previously shown are not the only factors that influence the spatial distribution of rainfall. Indeed, in these conditions it is expected less precipitation and a drier post-deforestation climate. 
In this context, the results suggest that the juxtaposition of deforested and forested areas, which differ greatly in their physical properties, can promote conditions to increased precipitation via a "vegetation breeze". The rainfall that we have seen over deforested lands usually comes from the evapotranspiration of water vapour above forest surrounding whereas the air tends to be cooled and increasing local pressure. Due to physical differences between contrasting types of vegetation cover the pressure gradient induce regional atmospheric circulations and transport moisture from surrounding forests into the deforested areas generating an increased cloudiness that may produce rainfall (Figure 2). This result is consistent with previous studies of tropical deforestation [38] [47] [50] [94] [95] [96] among others. For instance, Correia et al. [38] showed that these processes lead to an increase in the moisture convergence overcoming the effect of reduction of the evaporation and thus increasing the precipitation. The vertically integrated moisture flux change (Figure 2) give a coherent picture of the process described above, and from them we can see that forest clearings promote local atmospheric circulations that increase rainfall.

In sum, the results show the precipitation increase on the deforested areas is associated with the modification of the thermodynamic characteristics (evaporation, Bowen ratio, temperature), due to land cover change together with mesoscale circulation changes. It should be noted that most of studies that have been analysed the effects of large scale deforestation in climate model agree that deforestation strongly decreases rainfall in some parts of the Amazon basin.

Furthermore, the difference between this modelled results and observational results such as Butt et al. [97] that show delay in rainy season onset could be due to changes in mesoscale circulations (driven by land cover transitions), the total deforested area and mainly because the use of $\sim 50 \mathrm{~km}$ horizontal resolution that may limit the ability to resolve the structures of rainfall and cloudiness. The land surface model may also limit the results and comparison between modelling and observation results.

An exploratory analysis that allows a comparison between deforestation and control simulations with respect to its symmetry and dispersion is presented in Figure 3. The box plot is useful for analyzing the monthly variability of simulated rainfall in the study areas.

In both deforestation scenarios, $75 \%$ of the months of the year have median increased rainfall with statistical significance at $95 \%$ (Figure 3). However, the main differences between deforestation and control simulations occur in the extremes of the variability (the length of the whiskers), which is most evident in NEAMZ.

In the SAMZ area, the deforestation simulations show higher median valuesthan the control simulations, particularly between the months of November to May (months of the rainy season), highlighting an augmented accumulated rainfall over this period. In the driest months during the wintertime JJA season there is not much difference in the median values. During the months of transition between the dry and rainy season for August to October the differences of 


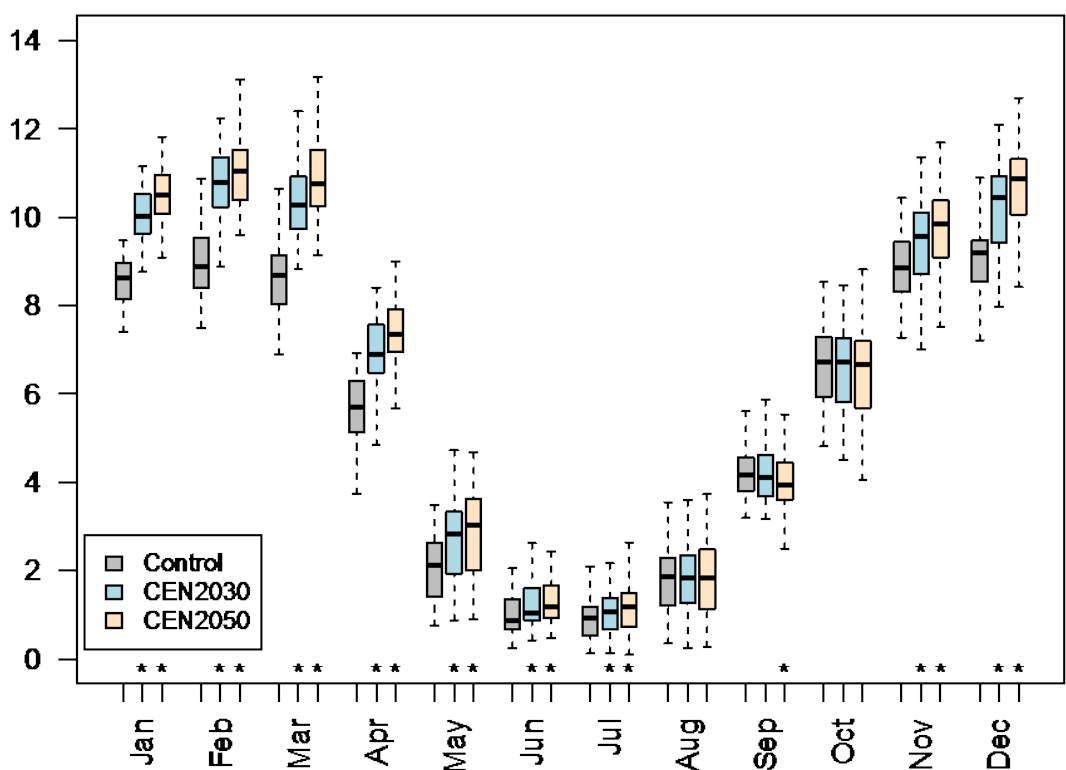

(a)

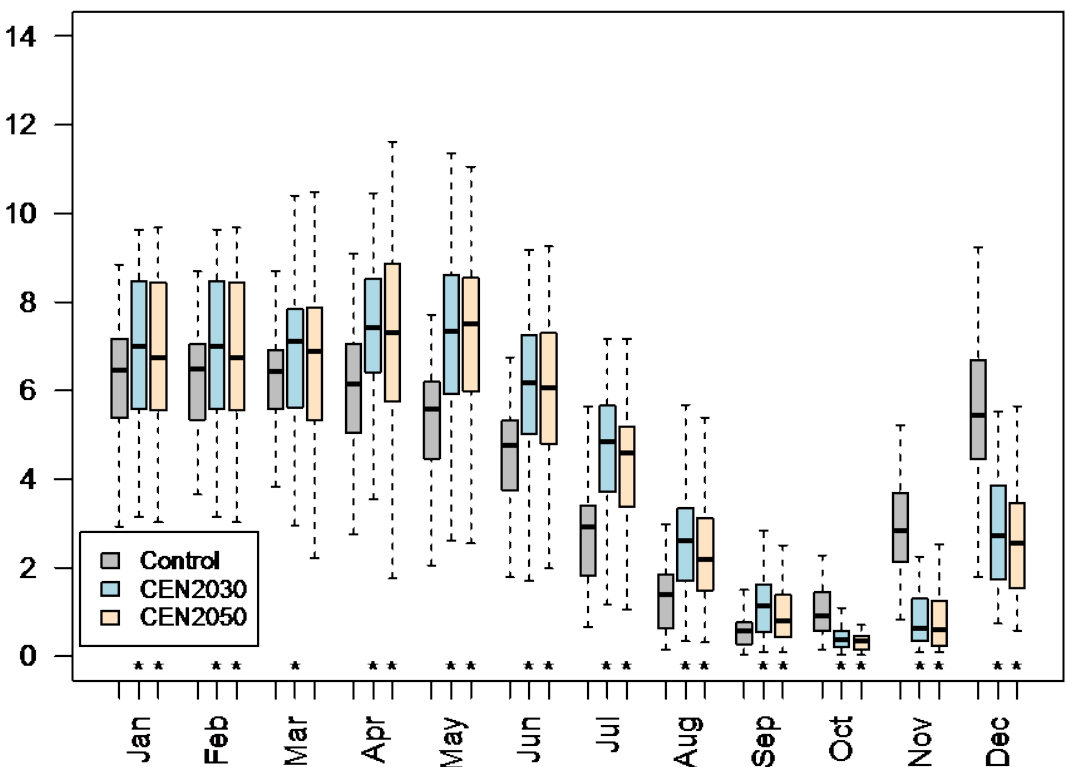

(b)

Figure 3. Boxplot of monthly mean precipitation ( $\mathrm{mm} /$ day) of the control (grey) and deforestation simulations (CEN2030-light blue e CEN2050-beige) at southern-SAMZ (a) and northeast-NEAMZ (b) Amazonia. Asterisks indicate statistically significant differences between control and deforestation simulations ( $p<0.05$, Student's $t$-test).

the median are small and not statistically significant. This indicates that the position of the median in any the three experiments, is statistically similar, although a small variability in the extremes can be observed.

The main difference in the NEAMZ is observed during the transition between the June-August dry season and the October to December rainy season, which presents a significant (to the level of 95\%) change in the central position (median) of its frequency distribution, with differences of $85 \mathrm{~mm}$ (October), $334 \mathrm{~mm}$ (November) and $432 \mathrm{~mm}$ (December) relative to control simulation. This suggests a 
possible change in the amplitude of the annual cycle in deforestation simulations. Moreover, the amplitude in the range of the whisker over this area is more evident in the deforestation simulations, suggesting a higher temporal variability of extreme events in every month of the year.

Furthermore, we analyzed the impact of vegetation change during the dry and rainy seasons for the control and deforestation simulations in both study areas (Table 3 and Table 4). We assess the onset of rainy season following Bombardi and Carvalho [83] for the different scenarios.

The rainy season over the SAMZ (Table 3) shows an average onset in early October (pentad 56), duration of 40 pentads and accumulated rainfall of 1670.4 $\mathrm{mm}$. Differences relative to the deforestation scenario (CEN2050) in this region are two-pentad late onset (pentad 58), reduction of one pentad in duration, and

Table 3. Climatological onset/demise dates (pentad), duration and accumulated rainfall of rainy and dry season in Southern Amazonia (SAMZ).

\begin{tabular}{cccc}
\hline Rainy season & CTRL & CEN2030 & CEN2050 \\
\hline Onset & 56 (3-7/Oct.) & 58 (13-17/Oct.) & 58 (13-17/Oct.) \\
Demise & 22 (16-20/Apr.) & 22 (16-20/Apr.) & 23 (21-25/Apr.) \\
Duration (pentad) & 40 & 38 & 39 \\
Accumulated rainfall (mm) & 1670.4 & 1873.9 & 1927.9 \\
\hline Dry season & & & \\
Onset & $23(21-25 /$ Apr. $)$ & $23(21-25 /$ Apr. $)$ & $24(26-30 /$ Apr. $)$ \\
Demise & $55(28 /$ Sep.-2/Oct.) & 57 (8-12/Oct.) & 57 (8-12/Oct.) \\
Duration (pentad) & 33 & 35 & 34 \\
Accumulated rainfall (mm) & 326.4 & 397.6 & 412.9 \\
\hline
\end{tabular}

Table 4. Climatological onset/demise dates (pentad), duration and accumulated rainfall of rainy and dry season in Northeast Amazonia (NEAMZ).

\begin{tabular}{|c|c|c|c|}
\hline Rainy season & CTRL & CEN2030 & CEN2050 \\
\hline Onset & 67 (27/Nov.-1/Dec.) & 67 (27/Nov.-1/Dec.) & 67 (27/Nov.-1/Dec.) \\
\hline Demise & 36 (26-29/Jun.) & 35 (20-24/Jun.) & 35 (20-24/Jun.) \\
\hline Duration (pentad) & 43 & 42 & 42 \\
\hline $\begin{array}{l}\text { Accumulated rainfall } \\
\qquad(\mathrm{mm})\end{array}$ & 1335.1 & 1544.6 & 1428.6 \\
\hline \multicolumn{4}{|l|}{ Dry season } \\
\hline Onset & 37 (30/Jun.-4/Jul.) & 36 (25-29/Jun.) & 36 (25-29/Jun.) \\
\hline Demise & 66 (22-26/Nov.) & 66 (22-26/Nov.) & 66 (22-26/Nov.) \\
\hline Duration (pentad) & 30 & 31 & 31 \\
\hline $\begin{array}{l}\text { Accumulated rainfall } \\
\qquad(\mathrm{mm})\end{array}$ & 245.3 & 271.0 & 252.7 \\
\hline
\end{tabular}


rainfall increase of $257 \mathrm{~mm}$, which indicates that a scenario of increasing deforestation could lead to abundant precipitation during the rainy season in that area. Besides, it also indicates a lengthening in the dry season of up to two pentads and rainfall increase of up to $87 \mathrm{~mm}$.

Over the NEAMZ, despite deforestation simulations indicate increased rainfall (as seen in Figure 2 and confirmed in Table 4), there is no change in the onset of the rainy season. In SAMZ, it is observed a decrease in the duration of the rainy season by one pentad with a premature onset of the dry season and increased accumulated rainfall. These results are consistent with earlier simulation studies of deforestation. For instance, Chen and Avissar [98] found that those mesoscale circulations could affect the length, duration and formation of clouds, therefore changing the intensity and distribution of the precipitation. Moreover, Costa and Pires [39] suggest that the total removal of the Cerrado, combined with the deforestation scenarios produced by Soares-Filho et al. [99] for 2030 and 2050, can induce a longer dry season in the transition region between forest and savannah. This change, suggested by numerical modeling, was actually observed by Butt et al. [97] in the historical series of rainfall in the state of Rondônia, and also by $\mathrm{Fu}$ et al. [100] in southern Amazon, starting from 1979, mainly due to a delayed end of the dry season.

One possible explanation for these changes could be that the drying of the earth's surface, represented by the Bowen ratio during the dry season, seems to be the main cause for changes in the regional circulation leading to a delayed onset of the next rainy season. Similar mechanisms were identified by $\mathrm{Fu}$ and $\mathrm{Li}$ [101]. This is due to increased evapotranspiration by the end of the dry season, associated with the seasonal increase in leaf area index (or greening of the rainforest), which are critical to the onset of the transition from dry to wet season.

The assessment of the rainfall extreme in those deforestation scenarios is shown in (Table 5 and Table 6). Although deforestation simulations initially indicate higher values of mean precipitation, especially during the rainy season, the SPI shows fewer rainy events and more frequent dry events in categories "extreme" and "very extreme", particularly in the scales of 3, 6 and 12 months. This indicates that any change in land cover has also an impact on the frequency of extreme rainfall events. This finding suggests that deforestation can affect the hydrological cycle on its seasonal and interannual time scales and the extremes in the region have direct effects on ecosystem characteristics and profound socioeconomic effects as seen in the droughts of 2005 and 2010. Characteristics of droughts or floods can be explained by increased seasonal and interannual variability due to changes in the regional circulation and convective activity in areas under the influence of deforestation.

These results are consistent with AGCM simulations where $20 \%$ to $70 \%$ of the models agree with the projected declined rainfall in the dry season over the Amazon, with the highest probability of drought in the eastern region [24].

\section{Conclusions}

This study has examined regional-scale patterns of rainfall variability in the 
Table 5. Frequency (\%) of the Standardized Precipitation Index (SPI) for extreme rainfall events at Southern Amazonia (SAMZ).

\begin{tabular}{|c|c|c|c|c|c|}
\hline & & \multicolumn{2}{|c|}{ Dry } & \multicolumn{2}{|c|}{ Wet } \\
\hline & & Severe & Extreme & Severe & Extreme \\
\hline \multirow[t]{4}{*}{ CTRL } & SPI1 & 4 & 2 & 4 & 1 \\
\hline & SPI3 & 4 & 1 & 4 & 1 \\
\hline & SPI6 & 4 & 2 & 4 & 1 \\
\hline & SPI12 & 3 & 2 & 4 & 2 \\
\hline \multirow[t]{4}{*}{ CEN2030 } & SPI1 & 3 & 3 & 4 & 1 \\
\hline & SPI3 & 5 & 1 & 6 & 0 \\
\hline & SPI6 & 4 & 3 & 4 & 1 \\
\hline & SPI12 & 3 & 4 & 2 & 1 \\
\hline \multirow[t]{4}{*}{ CEN2050 } & SPI1 & 3 & 3 & 3 & 1 \\
\hline & SPI3 & 3 & 2 & 3 & 1 \\
\hline & SPI6 & 2 & 3 & 2 & 0 \\
\hline & SPI12 & 3 & 3 & 2 & 0 \\
\hline
\end{tabular}

Table 6. Frequency (\%) of the Standardized Precipitation Index (SPI) for extreme rainfall events at Northeast Amazonia (NEAMZ).

\begin{tabular}{|c|c|c|c|c|c|}
\hline & & \multicolumn{2}{|c|}{ Dry } & \multicolumn{2}{|c|}{ Wet } \\
\hline & & Severe & Extreme & Severe & Extreme \\
\hline \multirow[t]{4}{*}{ CTRL } & SPI1 & 3 & 3 & 3 & 1 \\
\hline & SPI3 & 4 & 3 & 3 & 1 \\
\hline & SPI6 & 5 & 3 & 2 & 0 \\
\hline & SPI12 & 4 & 4 & 2 & 0 \\
\hline \multirow[t]{4}{*}{ CEN2030 } & SPI1 & 4 & 3 & 4 & 0 \\
\hline & SPI3 & 6 & 3 & 3 & 1 \\
\hline & SPI6 & 4 & 3 & 2 & 0 \\
\hline & SPI12 & 3 & 5 & 2 & 0 \\
\hline \multirow[t]{4}{*}{ CEN2050 } & SPI1 & 4 & 3 & 4 & 1 \\
\hline & SPI3 & 5 & 3 & 3 & 1 \\
\hline & SPI6 & 4 & 3 & 3 & 0 \\
\hline & SPI12 & 3 & 5 & 1 & 0 \\
\hline
\end{tabular}

Amazon region as related to deforestation scenarios. The PRECIS regional climate model system is used in performing sensitivity experiments of the climate of the Amazon basin. Specific objectives of this study were to assess potential impacts of land use change on the climate of Amazon basin particularly on changes on the seasonal rainfall variability and components of rainy season (timing, duration and rainfall frequency and intensity). 
The sensitivity experiments are performed for the month's austral summer DJF and winter June-August. The experiment consists of three runs using the PRECIS: a control run to simulate the pre-deforestation state and two perturbed runs to simulate the post-deforestation state based on scenarios of deforestation for Amazon produced by Aguiar et al. [61] for 2030 and 2050.

The main results are summarized as follows: deforestation leads to a warmer climate that together with less evaporation affects the energy balance at the surface and consequently leads to changes in pressure and regional circulation. It is noticed also that, land cover change predominantly has a local and only strong effect on precipitation in the core of the deforested region for both the wet and dry seasons as well as the annual mean. Deforestation locally leads to an increase in precipitation mainly in summer.

In both deforestation simulations, the impacts of the land cover change are highlighted over the "Arc of deforestation" and central-southen Amazon regions during whole year, however, it is worth emphasizing that the relative impact of the simulated changes is the greatest in the JJA dry season. This behaviour increases the susceptibility of Amazonia forest to the incidence of fires and the consequent injection of aerosols release by the smoke.

It is also noted that the main differences between deforestation and control simulations occur in the frequency of extremes of the variability in both study areas and the amplitude in the annual cycle is more evident in the NEAMZ and during the transition between the dry and rainy season. Over the SAMZ, the results indicate a lengthening in the dry season of up to two pentads and rainfall reduction of up to $26 \mathrm{~mm}$.

Although deforestation simulations initially indicate higher values of mean precipitation, especially during the rainy season, the SPI shows that the occurrence of extreme rainfall events is affected by deforestation mainly more frequent dry events in categories "extreme" and "very extreme" which has several environmental and economic impacts.

Presumably, this result from the fact that the deforestation plays an important role influences the land-precipitation feedbacks such as water recycling, the energy balance at the surface and the regional atmospheric circulation patterns, thus directly impacts the Amazonia climate.

From the literature review, and in a broader context, it is clear that deforestation affects the surface conditions, which usually means increased temperature and drier (and more reflective) soil surface. As a result, less energy is available for heating and moistening the atmosphere. In addition, lower evapotranspiration resulting from drier soil reduces rainfall and also contributes to the drier conditions.

It is also important to note that it is difficult to determine whether deforestation is the main cause of the increase in frequency of extreme dry events due to incorrect or incomplete description of key processes and feedbacks in RCM physics.

In summary, the impacts of deforestation on the Amazon rainy season depend 
in part on the use of converted forests and this varies by region. However, it should be pointed out that many other regional factors, such as soil type, distribution of land and water, and so on, are also important [51] [102] and considering the complex framework of factors and their interrelationships that affect the Amazon climate, it is essential that future studies should be considered with Earth System Models and human component including infrastructure and social policies.

\section{Acknowledgements}

The research leading to these results has received funding from the Rede-CLIMA, the National Institute of Science and Technology for Climate Change INCT-MC funded by CNPq, FAPESP-RCUK PULSE (2012/51876-0) and FAPESP/DOE/FAPEAMGoAmazongrant 2013/50538-7. We would like to thank the Hadley Centre for providing the PRECIS model system, boundary data for this study and PRECIS team for technical assistance.

\section{References}

[1] Aragão, L.E.O.C., Poulter, B., Barlow, J.B., Anderson, L.O., Malhi, Y., Saatchi, S., et al. (2014) Environmental Change and the Carbon Balance of Amazonian Forests. Biological Reviews, 89, 913-931. https://doi.org/10.1111/brv.12088

[2] Nobre, A.D. (2014) The Future Climate of Amazonia. São José dos Campos.

[3] Coe, M.T., Marthews, T.R., Costa, M.H., Galbraith, D.R., Greenglass, N.L., Imbuzeiro, H.M.A., et al. (2013) Deforestation and Climate Feedbacks Threaten the Ecological Integrity of South-Southeastern Amazonia. Philosophical Transactions of the Royal Society of London B: Biological Sciences, 368, Article ID: 20120155. https://doi.org/10.1098/rstb.2012.0155

[4] Zhang, K., de Almeida Castanho, A.D., Galbraith, D.R., Moghim, S., Levine, N.M., Bras, R.L., et al. (2015) The Fate of Amazonian Ecosystems over the Coming Century Arising from Changes in Climate, Atmospheric $\mathrm{CO}_{2}$, and Land Use. Global Change Biology, 21, 2569-2587.

[5] Magrin, G.O., Marengo, J.A., Boulanger, J.-P., Buckeridge, M.S., Castellanos, E., Poveda, G., et al. (2014) Central and South America. In: Barros, V.R., Field, C.B., Dokken, D.J., Mastrandrea, M.D., Mach, K.J., Bilir, T.E., et al., Eds., Climate Change 2014: Impacts, Adaptation, and Vulnerability. Part B: Regional Aspects, Cambridge University Press, Cambridge, 1499-1566.

[6] Marengo, J.A. and Espinoza, J.C. (2015) Extreme Seasonal Droughts and Floods in Amazonia: Causes, Trends and Impacts. International Journal of Climatology, 36, 1033-1050.

[7] Aguiar, A.P.D., Câmara, G. and Escada, M.I.S. (2007) Spatial Statistical Analysis of Land-Use Determinants in the Brazilian Amazonia: Exploring Intra-Regional Heterogeneity. Ecological Modelling, 209, 169-188.

https://doi.org/10.1016/j.ecolmodel.2007.06.019

[8] Dalla-Nora, E.L., de Aguiar, A.P.D., Lapola, D.M. and Woltjer, G. (2014) Why Have Land Use Change Models for the Amazon Failed to Capture the Amount of Deforestation over the Last Decade? Land Use Policy, 39, 403-411. https://doi.org/10.1016/j.landusepol.2014.02.004

[9] Salati, E., Dall'Olio, A., Matsui, E. and Gat, J.R. (1979) Recycling of Water in the 
Amazon Basin: An Isotopic Study. Water Resources Research, 15, 1250-1258. https://doi.org/10.1029/WR015i005p01250

[10] Figueroa, S.N. and Nobre, C.A. (1990) Precipitation Distribution over Central and Western Tropical South America. Climanálise, 5, 36-45.

[11] Ronchail, J., Cochonneau, G., Molinier, M., Guyot, J.-L., De Miranda Chaves, A.G., Guimarães, V., et al. (2002) Interannual Rainfall Variability in the Amazon Basin and Sea-Surface Temperatures in the Equatorial Pacific and the Tropical Atlantic Oceans. International Journal of Climatology, 22, 1663-1686. https://doi.org/10.1002/joc.815

[12] Espinoza Villar, J.C., Ronchail, J., Guyot, J.L., Cochonneau, G., Naziano, F., Lavado, W., et al. (2009) Spatio-Temporal Rainfall Variability in the Amazon Basin Countries (Brazil, Peru, Bolivia, Colombia and Ecuador). International Journal of Climatology, 29, 1574-1594. https://doi.org/10.1002/joc.1791

[13] Espinoza Villar, J.C., Guyot, J.L., Ronchail, J., Cochonneau, G., Filizola, N., Fraizy, P., et al. (2009) Contrasting Regional Discharge Evolutions in the Amazon Basin (1974-2004). Journal of Hydrology, 375, 297-311. https://doi.org/10.1016/j.jhydrol.2009.03.004

[14] Marengo, J.A., Tomasella, J., Soares, W.R., Alves, L.M. and Nobre, C.A. (2011) Extreme Climatic Events in the Amazon Basin. Theoretical and Applied Climatology, 107, 73-85.

[15] Sombroek, W. (2001) Spatial and Temporal Patterns of Amazon Rainfall. AMBIO. A Journal of the Human Environment, 30, 388-396. https://doi.org/10.1579/0044-7447-30.7.388

[16] Marengo, J.A., Tomasella, J., Alves, L.M., Soares, W.R. and Rodriguez, D.A. (2011) The Drought of 2010 in the Context of Historical Droughts in the Amazon Region. Geophysical Research Letters, 38, 1-5. https://doi.org/10.1029/2011gl047436

[17] Malhi, Y., Roberts, J.T., Betts, R.A, Killeen, T.J., Li, W. and Nobre, C.A. (2008) The Fate of the Amazon. Science, 319, 169-172. https://doi.org/10.1126/science.1146961

[18] Arraut, J.M., Nobre, C., Barbosa, H.M.J., Obregon, G. and Marengo, J. (2012) Aerial Rivers and Lakes: Looking at Large-Scale Moisture Transport and Its Relation to Amazonia and to Subtropical Rainfall in South America. Journal of Climate, 25, 543-556. https://doi.org/10.1175/2011JCLI4189.1

[19] Marengo, J.A., Soares, W.R., Saulo, C. and Nicolini, M. (2004) Climatology of the Low-Level Jet East of the Andes as Derived from the NCEP-NCAR Re-analyses: Characteristics and Temporal Variability. Journal of Climate, 17, 2261-2280. https://doi.org/10.1175/1520-0442(2004)017<2261:COTLJE $>2.0 . C O ; 2$

[20] Angelini, I.M., Garstang, M., Davis, R.E., Hayden, B., Fitzjarrald, D.R., Legates, D.R., et al. (2011) On the Coupling between Vegetation and the Atmosphere. Theoretical and Applied Climatology, 105, 243-261. https://doi.org/10.1007/s00704-010-0377-5

[21] Runyan, C.W., D’Odorico, P. and Lawrence, D. (2012) Physical and Biological Feedbacks of Deforestation. Reviews of Geophysics, 50, RG4006.

https://doi.org/10.1029/2012rg000394

[22] Makarieva, A.M., Gorshkov, V.G., Sheil, D., Nobre, A.D. and Li, B.-L. (2013) Where Do Winds Come from? A New Theory on How Water Vapor Condensation Influences Atmospheric Pressure and Dynamics. Atmospheric Chemistry and Physics, 13, 1039-1056. https://doi.org/10.5194/acp-13-1039-2013

[23] Costa, M.H. and Foley, J.A. (2000) Combined Effects of Deforestation and Doubled Atmospheric $\mathrm{CO}_{2}$ Concentrations on the Climate of Amazonia. Journal of Climate, 13, 18-34. https://doi.org/10.1175/1520-0442(2000)013<0018:CEODAD > 2.0.CO;2 
[24] Malhi, Y., Roberts, J.T., Betts, R.A., Killeen, T.J., Li, W. and Nobre, C.A. (2008) Climate Change, Deforestation and the Fate of the Amazon. Science, 319, 169-172. https://doi.org/10.1126/science.1146961

[25] Marengo, J.A., Nobre, C.A., Tomasella, J., Oyama, M.D., de Oliveira, S.G., de Oliveira, R., et al. (2008) The Drought of Amazonia in 2005. Journal of Climate, 21, 495-516. https://doi.org/10.1175/2007JCLI1600.1

[26] Zeng, N., Yoon, J.-H., Marengo, J.A., Subramaniam, A., Nobre, C.A., Mariotti, A., et al. (2008) Causes and Impacts of the 2005 Amazon Drought. Environmental Research Letters, 3, Article ID: 014002. https://doi.org/10.1088/1748-9326/3/1/014002

[27] Aragão, L.E.O.C., Malhi, Y., Barbier, N., Lima, A.A., Shimabukuro, Y., Anderson, L., et al. (2008) Interactions between Rainfall, Deforestation and Fires during Recent Years in the Brazilian Amazonia. Philosophical Transactions of the Royal Society of London. Series B, Biological Sciences, 363, 1779-1785. https://doi.org/10.1098/rstb.2007.0026

[28] Lewis, S.L., Brando, P.M., Phillips, O.L., van der Heijden, G.M.F. and Nepstad, D. (2011) The 2010 Amazon Drought. Science, 331, 554. https://doi.org/10.1126/science.1200807

[29] Gatti, L.V., Gloor, M., Miller, J.B., Doughty, C.E., Malhi, Y., Domingues, L.G., et al. (2014) Drought Sensitivity of Amazonian Carbon Balance Revealed by Atmospheric Measurements. Nature, 506, 76-80. https://doi.org/10.1038/nature12957

[30] Bonan, G.B. (2008) Forests and Climate Change: Forcings, Feedbacks and the Climate Benefits of Forests. Science, 320, 1444-1449. https://doi.org/10.1126/science.1155121

[31] Foley, J.A. (2005) Global Consequences of Land Use. Science, 309, 570-574. https://doi.org/10.1126/science.1111772

[32] Von Randow, C., Manzi, O.A., Kruijt, B., de Oliveira, J.P., Zanchi, B.F., Silva, L.R., et al. (2004) Comparative Measurements and Seasonal Variations in Energy and Carbon Exchange over Forest and Pasture in South West Amazonia. Theoretical and Applied Climatology, 78, 5-26. https://doi.org/10.1007/s00704-004-0041-Z

[33] Tomasella, J., Borma, L.S., Marengo, J.A., Rodriguez, D.A., Cuartas, L.A., Nobre, A.C., et al. (2011) The Droughts of 1996-1997 and 2004-2005 in Amazonia: Hydrological Response in the River Main-Stem. Hydrological Processes, 25, 1228-1242. https://doi.org/10.1002/hyp.7889

[34] Spracklen, D.V., Arnold, S.R. and Taylor, C.M. (2012) Observations of Increased Tropical Rainfall Preceded by Air Passage over Forests. Nature, 489, 282-285. https://doi.org/10.1038/nature11390

[35] Spracklen, D.V. and Garcia-Carreras, L. (2015) The Impact of Amazonian Deforestation on Amazon Basin Rainfall. Geophysical Research Letters, 42, 9546-9552. https://doi.org/10.1002/2015GL066063

[36] Nobre, C.A., Sellers, P.J. and Shukla, J. (1991) Amazonian Deforestation and Regional Climate Change. Journal of Climate, 4, 957-988. https://doi.org/10.1175/1520-0442(1991)004<0957:ADARCC>2.0.CO;2

[37] Avissar, R. and Werth, D. (2005) Global Hydroclimatological Teleconnections Resulting from Tropical Deforestation. Journal of Hydrometeorology, 6, 134-145. https://doi.org/10.1175/JHM406.1

[38] Correia, F.W.S., Alvalá, R.C.S. and Manzi, A.O. (2008) Modeling the Impacts of Land Cover Change in Amazonia: A Regional Climate Model (RCM) Simulation Study. Theoretical and Applied Climatology, 93, 225-244. https://doi.org/10.1007/s00704-007-0335-Z

[39] Costa, M.H. and Pires, G.F. (2010) Effects of Amazon and Central Brazil Deforesta- 
tion Scenarios on the Duration of the Dry Season in the Arc of Deforestation. International Journal of Climatology, 30, 1970-1979. https://doi.org/10.1002/joc.2048

[40] Werth, D. and Avissar, R. (2002) The Local and Global Effects of Amazon Deforestation. Geophysical Research, 107, 391-401.

[41] Gash, J.H.C., Nobre, C.A., Roberts, J.M. and Victoria, R.L. (1996) Amazonian Deforestation and Climate. John Wiley, Hoboken.

[42] Henderson-Sellers, A. and Gornitz, V. (1984) Possible Climatic Impacts of Land Cover Transformations, with Particular Emphasis on Tropical Deforestation. Climatic Change, 6, 231-257. https://doi.org/10.1007/BF00142475

[43] Hirota, M., Holmgren, M., Van Nes, E.H. and Scheffer, M. (2011) Global Resilience of Tropical Forest and Savanna to Critical Transitions. Science, 334, 232-235. https://doi.org/10.1126/science.1210657

[44] Medvigy, D., Walko, R.L. and Avissar, R. (2011) Effects of Deforestation on Spatiotemporal Distributions of Precipitation in South America. Journal of Climate, 24, 2147-2163. https://doi.org/10.1175/2010JCLI3882.1

[45] Oyama, M.D. (2003) A New Climate-Vegetation Equilibrium State for Tropical South America. Geophysical Research Letters, 30, 2199.

https://doi.org/10.1029/2003gl018600

[46] Sampaio, G., Nobre, C., Costa, M.H., Satyamurty, P., Soares-Filho, B.S. and Cardoso, M. (2007) Regional Climate Change over Eastern Amazonia Caused by Pasture and Soybean Cropland Expansion. Geophysical Research Letters, 34, L17709. https://doi.org/10.1029/2007gl030612

[47] Lejeune, Q., Davin, E.L., Guillod, B.P. and Seneviratne, S.I. (2014) Influence of Amazonian Deforestation on the Future Evolution of Regional Surface Fluxes, Circulation, Surface Temperature and Precipitation. Climate Dynamics, 44, 2769-2786.

[48] Lima, L.S., Coe, M.T., Soares Filho, B.S., Cuadra, S.V., Dias, L.C.P., Costa, M.H., et al. (2014) Feedbacks between Deforestation, Climate and Hydrology in the Southwestern Amazon: Implications for the Provision of Ecosystem Services. Landscape Ecology, 29, 261-274. https://doi.org/10.1007/s10980-013-9962-1

[49] Nobre, P., Malagutti, M., Urbano, D.F., de Almeida, R.A.F. and Giarolla, E. (2009) Amazon Deforestation and Climate Change in a Coupled Model Simulation. Journal of Climate, 22, 5686-5697. https://doi.org/10.1175/2009JCLI2757.1

[50] Da Silva, R.R., Werth, D. and Avissar, R. (2008) Regional Impacts of Future LandCover Changes on the Amazon Basin Wet-Season Climate. Journal of Climate, 21, 1153-1170. https://doi.org/10.1175/2007JCLI1304.1

[51] D’Almeida, C., Vörösmarty, C.J., Hurtt, G.C., Marengo, J.A., Dingman, S.L. and Keim, B.D. (2007) The Effects of Deforestation on the Hydrological Cycle in Amazonia: A Review on Scale and Resolution. International Journal of Climatology, 27, 633-647. https://doi.org/10.1002/joc.1475

[52] Koster, R.D., Dirmeyer, P.A., Hahmann, A.N., Ijpelaar, R., Tyahla, L., Cox, P., et al. (2002) Comparing the Degree of Land-Atmosphere Interaction in Four Atmospheric General Circulation Models. Journal of Hydrometeorology, 3, 363-375. https://doi.org/10.1175/1525-7541(2002)003<0363:CTDOLA >2.0.CO;2

[53] Andreae, M.O., Rosenfeld, D., Artaxo, P., Costa, A.A., Frank, G.P., Longo, K.M., et al. (2004) Smoking Rain Clouds over the Amazon. Science, 303, 1337-1342. https://doi.org/10.1126/science.1092779

[54] Lee, J.-E., Lintner, B.R., Boyce, C.K. and Lawrence, P.J. (2011) Land Use Change Exacerbates Tropical South American Drought by Sea Surface Temperature Variability. Geophysical Research Letters, 38, L19706.

[55] Cox, P.M., Betts, R.A., Jones, C.D., Spall, S.A. and Totterdell, I.J. (2000) Accelera- 
tion of Global Warming Due to Carbon-Cycle Feedbacks in a Coupled Climate Model. Nature, 408, 184-187. https://doi.org/10.1038/35041539

[56] Cox, P.M., Betts, R.A., Collins, M., Harris, P.P., Huntingford, C. and Jones, C.D. (2004) Amazonian Forest Dieback under Climate-Carbon Cycle Projections for the 21st Century. Theoretical and Applied Climatology, 78, 137-156. https://doi.org/10.1007/s00704-004-0049-4

[57] Salazar, L.F., Nobre, C.A. and Oyama, M.D. (2007) Climate Change Consequences on the Biome Distribution in Tropical South America. Geophysical Research Letters, 34, L09708.

[58] Shukla, J., Nobre, C. and Sellers, P. (1990) Amazon Deforestation and Climate Change. Science, 247, 1322-1325. https://doi.org/10.1126/science.247.4948.1322

[59] Malhi, Y., Aragão, L.E.O.C., Galbraith, D., Huntingford, C., Fisher, R., Zelazowski, P., et al. (2009) Exploring the Likelihood and Mechanism of a Climate-Change-Induced Dieback of the Amazon Rainforest. Proceedings of the National Academy of Sciences of the United States of America, 106, 20610-20615. https://doi.org/10.1073/pnas.0804619106

[60] Xue, Y., Fennessy, M.J. and Sellers, P.J. (1996) Impact of Vegetation Properties on U.S. Summer Weather Prediction. Journal of Geophysical Research: Atmospheres, 101, 7419-7430. https://doi.org/10.1029/95JD02169

[61] Aguiar, A.P.D., Vieira, I.C.G., Assis, T.O., Dalla-Nora, E.L., de Toledo, P.M., de Oliveira Santos-Junior, R.A., et al. (2015) Land Use Change Emission Scenarios: Anticipating a Forest Transition Process in the Brazilian Amazon? Global Change Biology, 22, 1821-1840.

[62] IPCC (2014) Climate Change 2013-The Physical Science Basis. Cambridge University Press, Cambridge.

[63] IPCC (2012) Managing the Risks of Extreme Events and Disasters to Advance Climate Change Adaptation. A Special Report of Working Groups I and II of the Intergovernmental Panel on Climate Change. Cambridge University Press, Cambridge and New York.

[64] Nobre, C.A. and Borma, L.D.S. (2009) “Tipping Points" for the Amazon Forest. Current Opinion in Environmental Sustainability, 1, 28-36. https://doi.org/10.1016/j.cosust.2009.07.003

[65] Jones, R.G., Noguer, M., Hassell, D.C., Hudson, D., Wilson, S.S., Jenkins, G.J., et al. (2004) Generating High Resolution Climate Change Scenarios Using PRECIS. Met Office Hadley Centre, Exeter.

[66] Buontempo, C., Mathison, C., Jones, R., Williams, K., Wang, C. and McSweeney, C. (2015) An Ensemble Climate Projection for Africa. Climate Dynamics, 44, 2097 2118. https://doi.org/10.1007/s00382-014-2286-2

[67] Wei, X., Declan, C., Erda, L., Xu, Y.L., Hui, J., Jiang, J.H., et al. (2009) Future Cereal Production in China: The Interaction of Climate Change, Water Availability and Socio-Economic Scenarios. Global Environmental Change, 19, 34-44. https://doi.org/10.1016/j.gloenvcha.2008.10.006

[68] Marengo, J.A., Ambrizzi, T., da Rocha, R.P., Alves, L.M., Cuadra, S.V., Valverde, M.C., et al. (2009) Future Change of Climate in South America in the Late TwentyFirst Century: Intercomparison of Scenarios from Three Regional Climate Models. Climate Dynamics, 35, 1073-1097. https://doi.org/10.1007/s00382-009-0721-6

[69] Alves, L.M. and Marengo, J. (2010) Assessment of Regional Seasonal Predictability Using the PRECIS Regional Climate Modeling System over South America. Theoretical and Applied Climatology, 100, 337-350. https://doi.org/10.1007/s00704-009-0165-2 
[70] Islam, S., Rehman, N. and Sheikh, M.M. (2009) Future Change in the Frequency of Warm and Cold Spells over Pakistan Simulated by the PRECIS Regional Climate Model. Climatic Change, 94, 35-45. https://doi.org/10.1007/s10584-009-9557-7

[71] Karmalkar, A.V., Bradley, R.S. and Diaz, H.F. (2011) Climate Change in Central America and Mexico: Regional Climate Model Validation and Climate Change Projections. Climate Dynamics, 37, 605-629. https://doi.org/10.1007/s00382-011-1099-9

[72] Campbell, J.D., Taylor, M.A., Stephenson, T.S., Watson, R.A. and Whyte, F.S. (2011) Future Climate of the Caribbean from a Regional Climate Model. International Journal of Climatology, 31, 1866-1878. https://doi.org/10.1002/joc.2200

[73] Marengo, J.A., Jones, R., Alves, L.M. and Valverde, M.C. (2009) Future Change of Temperature and Precipitation Extremes in South America as Derived from the PRECIS Regional Climate Modeling System. International Journal of Climatology, 29, 2241-2255. https://doi.org/10.1002/joc.1863

[74] Gordon, C., Cooper, C., Senior, C.A., Banks, H., Gregory, J.M., Johns, T.C., et al. (2000) The Simulation of SST, Sea Ice Extents and Ocean Heat Transports in a Version of the Hadley Centre Coupled Model without Flux Adjustments. Climate Dynamics, 16, 147-168. https://doi.org/10.1007/s003820050010

[75] Pope, V.D., Gallani, M.L., Rowntree, P.R. and Stratton, R.A. (2000) The Impact of New Physical Parametrizations in the Hadley Centre Climate Model: HadAM3. Climate Dynamics, 16, 123-146. https://doi.org/10.1007/s003820050009

[76] Jones, R., Murphy, J., Hassell, D. and Taylor, R. (2001) Ensemble Mean Changes in a Simulation of the European Climate of 2071-2100 Using the New Hadley Centre Regional Modelling System HadAM3H/HadRM3H (DEFRA Report 2/2/01). Bracknell.

[77] Cox, P.M., Betts, R.A., Bunton, C.B., Essery, R.L.H., Rowntree, P.R. and Smith, J. (1999) The Impact of New Land Surface Physics on the GCM Simulation of Climate and Climate Sensitivity. Climate Dynamics, 15, 183-203. https://doi.org/10.1007/s003820050276

[78] Wilson, M.F. and Henderson-Sellers, A. (1985) A Global Archive of Land Cover and Soils Data for Use in General Circulation Climate Models. Journal of Climatology, 5, 119-143. https://doi.org/10.1002/joc.3370050202

[79] Collins, M., Booth, B.B.B., Harris, G.R., Murphy, J.M., Sexton, D.M.H. and Webb, M.J. (2006) Towards Quantifying Uncertainty in Transient Climate Change. Climate Dynamics, 27, 127-147. https://doi.org/10.1007/s00382-006-0121-0

[80] Chou, S.C., Marengo, J.A., Lyra, A.A., Sueiro, G., Pesquero, J.F., Alves, L.M., et al. (2012) Downscaling of South America Present Climate Driven by 4-Member HadCM3 Runs. Climate Dynamics, 38, 635-653.

https://doi.org/10.1007/s00382-011-1002-8

[81] Marengo, J.A., Chou, S.C., Kay, G., Alves, L.M., Pesquero, J.F., Soares, W.R., et al. (2012) Development of Regional Future Climate Change Scenarios in South America Using the Eta CPTEC/HadCM3 Climate Change Projections: Climatology and Regional Analyses for the Amazon, São Francisco and the Paraná River Basins. Climate Dynamics, 38, 1829-1848. https://doi.org/10.1007/s00382-011-1155-5

[82] Liebmann, B. and Marengo, J. (2001) Interannual Variability of the Rainy Season and Rainfall in the Brazilian Amazon Basin. Journal of Climate, 14, 4308-4318. https://doi.org/10.1175/1520-0442(2001)014<4308:IVOTRS>2.0.CO;2

[83] Bombardi, R.J. and Carvalho, L.M.V. (2008) IPCC Global Coupled Model Simulations of the South America Monsoon System. Climate Dynamics, 33, 893-916. https://doi.org/10.1007/s00382-008-0488-1 
[84] Mckee, T.B., Doesken, N.J. and Kleist, J. (1993) The Relationship of Drought Frequency and Duration to Time Scales. 8th Conference on Applied Climatology, Anaheim, 17-22 January 1993, 179-184.

[85] WMO (2012) Standardized Precipitation Index User Guide (WMO-No. 1090). Geneva.

[86] Panofsky, H.A. and Brier, G.W. (1968) Some Applications of Statistics to Meteorology. Earth and Mineral Sciences Continuing Education, College of Earth and Mineral Sciences.

[87] Rocha, E.J.P. (2001) Balanço de umidade e influência de condições de contorno superficiais sobre a precipitação da Amazônia, Instituto Nacional de Pesquisas Espaciais, 2001.

[88] Voldoire, A. and Royer, J.F. (2004) Tropical Deforestation and Climate Variability. Climate Dynamics, 22. https://doi.org/10.1007/s00382-004-0423-Z

[89] Findell, K.L., Shevliakova, E., Milly, P.C.D. and Stouffer, R.J. (2007) Modeled Impact of Anthropogenic Land Cover Change on Climate. Journal of Climate, 20, 3621-3634. https://doi.org/10.1175/JCLI4185.1

[90] Baidya Roy, S. and Avissar, R. (2002) Impact of Land Use/Land Cover Change on Regional Hydrometeorology in Amazonia. Journal of Geophysical Research, 107, 8037. https://doi.org/10.1029/2000JD000266

[91] Saad, S.I., da Rocha, H.R., Silva Dias, M.A.F. and Rosolem, R. (2010) Can the Deforestation Breeze Change the Rainfall in Amazonia? A Case Study for the BR-163 Highway Region. Earth Interactions, 14, 1-25. https://doi.org/10.1175/2010EI351.1

[92] Martin, S.T., Artaxo, P., Machado, L.A.T., Manzi, A.O., Souza, R.A.F., Schumacher, C., et al. (2015) Introduction: Observations and Modeling of the Green Ocean Amazon (GoAmazon2014/5). Atmospheric Chemistry and Physics Discussions, 15, 30175-30210. https://doi.org/10.5194/acpd-15-30175-2015

[93] Silva Dias, M.A., Avissar, R. and Silva Dias, P. (2009) Modeling the Regional and Remote Climatic Impact of Deforestation. In: Keller, M., Bustamante, M., Gash, J. and Dias, P.S., Eds., Amazonia and Global Change, American Geophysical Union, Washington DC, 251-260. https://doi.org/10.1029/2008GM000817

[94] Avissar, R., Dias, P.L.S., Dias, M.A.F.S. and Nobre, C.A. (2002) The Large-Scale Biosphere-Atmosphere Experiment in Amazonia (LBA): Insights and Future Research Needs. Journal of Geophysical Research, 107, LBA 54. https://doi.org/10.1029/2002JD002704

[95] Baidya Roy, S. and Avissar, R. (2000) Scales of Response of the Convective Boundary Layer to Land-Surface Heterogeneity. Geophysical Research Letters, 27, 533-536. https://doi.org/10.1029/1999GL010971

[96] Silva Dias, M.A.F. and Regnier, P. (1996) Simulation of Mesoscale Circulations in a Deforested Area of Rondonia in the Dry Season. In: Gash, J., Nobre, C., Roberts, J. and Victoria, R., Eds., Amazon Deforestation Climate, Wiley, Hoboken, 531-547.

[97] Butt, N., de Oliveira, P.A. and Costa, M.H. (2011) Evidence That Deforestation Affects the Onset of the Rainy Season in Rondonia, Brazil. Journal of Geophysical Research, 116, D11120. https://doi.org/10.1029/2010JD015174

[98] Chen, F. and Avissar, R. (1994) The Impact of Land-Surface Wetness Heterogeneity on Mesoscale Heat Fluxes. Journal of Applied Meteorology, 33, 1323-1340. https://doi.org/10.1175/1520-0450(1994)033<1323:TIOLSW >2.0.CO;2

[99] Soares-Filho, B.S., Nepstad, D.C., Curran, L.M., Cerqueira, G.C., Garcia, R.A., Ramos, C.A., et al. (2006) Modelling Conservation in the Amazon Basin. Nature, 440, 520-523. https://doi.org/10.1038/nature04389 
[100] Fu, R., Yin, L., Li, W., Arias, P.A., Dickinson, R.E., Huang, L., et al. (2013) Increased Dry-Season Length over Southern Amazonia in Recent Decades and Its Implication for Future Climate Projection. Proceedings of the National Academy of Sciences, 110, 18110-18115. https://doi.org/10.1073/pnas.1302584110

[101] Fu, R. and Li, W. (2004) The Influence of the Land Surface on the Transition from Dry to Wet Season in Amazonia. Theoretical and Applied Climatology, 78, 97-110. https://doi.org/10.1007/s00704-004-0046-7

[102] Mahmood, R., Pielke, R.A., Hubbard, K.G., Niyogi, D., Dirmeyer, P.A., McAlpine, C., et al. (2014) Land Cover Changes and Their Biogeophysical Effects on Climate. International Journal of Climatology, 34, 929-953. https://doi.org/10.1002/joc.3736

Submit or recommend next manuscript to SCIRP and we will provide best service for you:

Accepting pre-submission inquiries through Email, Facebook, LinkedIn, Twitter, etc. A wide selection of journals (inclusive of 9 subjects, more than 200 journals)

Providing 24-hour high-quality service

User-friendly online submission system

Fair and swift peer-review system

Efficient typesetting and proofreading procedure

Display of the result of downloads and visits, as well as the number of cited articles Maximum dissemination of your research work

Submit your manuscript at: http://papersubmission.scirp.org/

Or contact ajcc@scirp.org 